\title{
PROPAGANDA HAK ANGKET DPR TERHADAP KPK (Analisis Propaganda dan Komunikasi Politik)
}

\author{
Yopy Perdana Kusuma \\ Program Studi Ilmu Komunikasi Universitas Muhammadiyah Tangerang \\ Email: perdana_aspro@yahoo.com
}

\begin{abstract}
The investigation of the E-KTP case that dragged some members of DPR led to the formation of Pansus Hak Angket KPK. Instead of exploring information about the function of eradicating corruption, the formation of Pansus Hak Angket KPK is tend to be political propaganda in improving the image of DPR. This can be seen from how the using of vertical communication channel (especially through the mass media) rather than the horizontal communication channel. Moreover, the initial goal of Pansus Hak Angket KPK is to urge KPK to open a recording of the examination of Miryam Haryani who became a suspect in the case of $E$ KTP. This research uses qualitative methods to disquss the propaganda of DPR against KPK. With descriptive method, this research is to describe what and how propaganda DPR against KPK. From the various issues raised by Pansus Hak Angket KPK, it is seen how the formation of Pansus is irrelevant, because the existing problems can be solved through working meetings between DPR and KPK. Meanwhile, the communication channels tend to be more done vertically (especially through the mass media) rather than horizontally. In addition, DPR as a political communicator does not have adequate credibility in conducting propaganda against KPK. The public is also more confident of KPK rather than DPR. This research concludes that the formation of Pansus Hak Angket is full of political interests, became a political propaganda to improve the image of DPR and to strike down KPK rather than seeking truth or strengthening KPK.
\end{abstract}

Keywords: Political Propaganda, DPR-RI, Hak Angket, KPK, Combating Corruption.

\section{PENDAHULUAN}

Dewan Perwakilan Rakyat (DPR-RI) melalui rapat paripurna secara resmi mengesahkan pembentukan Panitia Khusus Hak Angket Komisi Pemberantasan Korupsi (Pansus Hak Angket KPK) pada 30 Mei 2017. Pansus Hak Angket KPK tetap dibentuk meskipun ada banyak penolakan baik dari masyarakat maupun dari beberapa fraksi di DPR itu sendiri. Selama masa kerja 60 hari, Pansus Hak Angket akan bekerja menggali keterangan mengenai fungsi pemberantasan korupsi yang dilakukan KPK.

Dalam proses pembentukannya, pada awalnya hanya 5 (lima) fraksi yang menempatkan perwakilan di dalam Pansus: Fraksi Partai Demokrasi IndonesiaPerjuangan (PDI-P), Fraksi Partai Persatuan Pembangunan (PPP), Fraksi Partai Nasional
Demokrat (Nasdem), Fraksi Partai Hati Nurani Rakyat (Hanura) dan Fraksi Partai Golongan Karya (Golkar). Dalam perkembangannya, Fraksi Partai Gerakan Indonesia Raya (Gerindra) dan Fraksi Partai Amanat Nasional (PAN) yang semula menolak mengirimkan wakil, berbalik arah dan mengirim perwakilan ke dalam Pansus. Saat ini, anggota Pansus Hak Angket KPK berasal dari 7 Fraksi dengan total perwakilan sebanyak 23 anggota. Pansus Hak Angket KPK dipimpin Agun Gunandjar dari Fraksi Golkar yang terpilih melalui rapat tertutup Pansus Hak Angket KPK pada7 Juni 2017.

Meskipun sudah disahkan, keberadaan Pansus Hak Angket KPK menuai banyak kritik dari berbagai kalangan masyarakat. Kecurigaan akan adanya konflik kepentingan (conflict of interest) pun mengemuka, karena 
latar belakang usulan Hak Angket tersebut adalah mendesak KPK agar membuka rekaman pemeriksaan Miryam Haryani, anggota DPR yang menjadi tersangka karena telah memberikan keterangan palsu dalam kasus korupsi E-KTP.

Hak Angket sendiri diatur dalam pasal 79 ayat (3) Undang-undang No.17 tahun 2014 yang menyebutkan bahwa Hak Angket merupakan hak DPR untuk melakukan penyelidikan terhadap pelaksanaan undangundang dan/atau kebijakan pemerintah yang berkaitan dengan hal penting, strategis, dan berdampak luas pada kehidupan bermasyarakat, berbangsa, bernegara yang diduga bertentangan dengan peraturan perundang-undangan.

Berdasarkan pasal tersebut, Hak Angket yang bisa dilakukan DPR terbatas pada penyidikan terhadap undang-undang atau kebijakan pemerintah yang bersifat penting, strategis, berdampak luas dan bertentangan dengan peraturan perundangundangan. Jika mengacu kepada pasal tersebut, maka sebenarnya DPR tidak dapat mengajukan Hak Angket terhadap KPK, sebab KPK sebagai lembaga negara sama sekali tidak melakukan pelanggaran hukum yang penting, strategis dan berdampak luas dalam melaksanakan tugas dan kewajibannya.

Pada sisi lain, Pansus Hak Angket KPK memiliki pertimbangan tersendiri dalam menjalani kerja-kerjanya, antara lain berdasarkan 7 indikasi ketidakpatuhan terhadap peraturan perundang-undangan sebagaimana tertuang di dalam Laporan Hasil Pemeriksaan (LHP) kepatuhan KPK tahun 2015 terkait tata kelola anggaran.

Selain terkait tata kelola anggaran, Komisi III juga mendapatkan masukan serta informasi terkait tata kelola dokumentasi di dalam proses hukum penindakan dugaan korupsi seperti pembocoran dokumen BAP, sprindik dan surat cekal.

Pembentukan Pansus Hak Angket KPK tersebut pun berujung pada konflik antara DPR dan KPK. Pada satu sisi, DPR bersikukuh bahwa pembentukan pansus merupakan kewenangannya sebagai lembaga legislatif dan sesuai dengan aturan yang ada. Namun di sisi lain, citra DPR yang dianggap buruk di mata masyarakat menimbulkan spekulasi yang mengarah pada 'opini' bahwa DPR sedang berupaya melemahkan KPK. Selain itu manuver politik yang sedang dilakukan DPR dengan menggulirkan Hak Angket kepada KPK juga dapat dicurigai sebagai upaya untuk menghambat pemeriksaan dan penyidikan kasus E-KTP. Terlebih, Ketua DPR-RI Setya Novanto sudah ditetapkan sebagai tersangka.

Karena saluran komunikasi yang dimanfaatkan lebih banyak menggunakan saluran komunikasi vertikal (khususnya media massa) dan kurang memanfaatkan saluran komunikasi horizontal (komunikasi antarlembaga), maka perang opini pun tak bisa dihindari. Berbagai berita yang ditampilkan di berbagai media massa baik nasional maupun lokal tidak terlepas dari propaganda masing-masing pihak yang bertahan dengan pendiriannya masingmasing.

\section{KAJIAN PUSTAKA Propaganda}

Propaganda adalah suatu kegiatan komunikasi yang erat kaitannya dengan persuasi. Menurut Laswell, propaganda adalah proses diseminasi informasi untuk memengaruhi sikap dan tingkah laku seseorang/kelompok masyarakat dengan motif indoktrinasi ideologi (dalam Cangara, 2009). Laswell melihat propaganda dapat membawa masyarakat ke dalam situasi bingung, raguragu dan terpaku kepada sesuatu yang licik dan tampaknya menipu.

Menurut Ellul (dalam Nimmo, 2006), ada dua tipologi propaganda: propaganda politik dan sosiologi. Propaganda politik melibatkan usaha-usaha pemerintah, partai atau golongan yang berpengaruh untuk mencapai tujuan strategis/taktis melalui imbauan-imbauan khas berjangka pendek, biasanya dilakukan secara terang-terangan, seperti yang terkait kebijakan dan regulasi. 
Propaganda sosiologi dapat dikatakan samar (tersembunyi) dan berjalan dalam rentang waktu yang panjang. Dengan cara ini, orang atau masyarakat tertentu ditanamkan (disuntik) dengan cara/gaya hidup budaya tertentu (seperti gaya hidup, fashion, musik Amerika yang ditiru banyak masyarakat dunia) atau ideologi yang berangsur-angsur merembes dalam tatanan struktur masyarakat, lembaga-lembaga ekonomi, sosial, budaya dan politik.

Menurut Nimmo (2006), propaganda politik adalah mekanisme kontrol sosial. Propagandis berbicara seolah-olah ada di antara dua orang yang bertatap muka untuk memberikan pesan bahwa pemimpin dan yang dipimpin tergabung dalam suatu pihak. Akan tetapi, seorang propagandis sebenarnya hanyalah wakil atau petugas dari organisasi yang secara teknis melakukan suatu upaya berdasarkan prosedur/panduan, memilih katakata yang tepat dan tindakannya berdasarkan alasan-alasan yang sifatnya teknis sematamata. Jadi, propagandis adalah teknisi kontrol sosial.

Di samping propaganda politik dan sosiologi, ada juga propaganda agitasi dan propaganda integrasi. Propaganda agitasi berusaha agar orang-orang mau berkorban lebih besar lagi bagi sebuah tujuan. Dengan agitasi, para pemimpin mempertahankan kegairahan para pengikutnya dengan cara memperoleh kemenangan yang khas, kemudian memberi peluang untuk bernafas dan diikuti usaha lain dengan inovasi dalam serangkaian tujuan. Propaganda integrasi bertujuan menggalang kesesuaian agar meraih tujuan jangka panjang. Melalui propaganda ini, orang-orang mengabdikan dirinya kepada tujuan-tujuan yang mungkin tidak terwujud dalam waktu bertahun-tahun, bahkan selama mereka hidup.

Dalam melakukan propaganda, ada dua saluran yang bisa dipakai propagandis: vertikal dan horizontal. Melalui saluran vertikal, penyebaran informasi dilakukan lewat media massa dan media baru. Pada propaganda horizontal, yang bekerja pada arus yang sejajar antara anggota kelompok, penyebaran informasi dilakukan lebih melalui komunikasi interpersonal dan komunikasi organisasi. Partai-partai politik cenderung mengandalkan propaganda secara horizontal dalam bentuk kunjungan ke daerah-daerah, pelatihan kader partai dan lain sebagainya (dalam Shahreza dan El-Yana, 2016).

Upaya persuasi melalui propaganda harus memperhatikan sejumlah faktor, yaitu memahami kondisi atau keadaan khayalak, kemampuan sosok propagandis dan teknik propaganda yang digunakan.

\section{Media Massa dan Komunikasi Politik}

Media massa merupakan aktor penting dalam demokrasi modern. Pada masyarakat yang mayoritas menggunakan media sebagai alat untuk mendapatkan informasi, agenda setting media sangat berpengaruh kuat. Masyarakat menentukan pilihan/keputusan politik berdasarkan informasi yang diperoleh melalui media. Disadari atau tidak oleh si pengguna media, agenda setting media di bidang politik mengarahkan pemikiran dan sikap politik pengguna media (McCombs dan Shaw, 1972).

Keadaan ini mengantarkan media massa menjadi sumber dominan tidak saja bagi individu, namun juga bagi masyarakat dalam memperoleh gambaran dan citra realitas sosial. Asumsi ini didukung oleh berbagai teori tentang hubungan media dan khalayak: stimulus-respon, agenda setting, the spiral of silence, cultivation dan lain-lain. Teori-teori ini secara umum menjelaskan bahwa apabila media memberi tekanan pada suatu peristiwa maka ia akan memengaruhi publik supaya menganggapnya penting. Pada perspektif ini, media tidak menentukan what to think, namun what to think about.

Nilai penting media massa (seperti radio, surat kabar, majalah dan televisi) yang paling jelas ialah kemampuannya dalam menjangkau jumlah audiens yang tidak terbatas. Menurut John Keane dalam The Media and Democracy (1991), perkembangan media massa selalu beriringan dengan aspirasi 
demokrasi dan perjuangan untuk meraih kekuasaan politik. Media massa telah menjadi fokus dari kompleksitas aktivitas politik yang terbaru. Demokrasi tradisional yang sebelumnya terfokus pada masifikasi, berganti menjadi fragmentasi. Dengan situasi yang tak kalah rumit dan dinamisnya, media dan politik akan berkembang menuju situasi yang saling terikat satu sama lain.

Meskipun penggunaan media pada proses komunikasi dan bentuk-bentuk komunikasi (agitasi, propaganda, public relations dan kampanye) tidak secara langsung menimbulkan prilaku tertentu, tetapi cenderung ikut memengaruhi bagaimana manusia mengorganisasikan citra politiknya dan membangun opini publik. Hal itulah yang selanjutnya akan memengaruhi cara manusia berpendapat (beropini) dan berperilaku.

Dukungan dari media atas aktivitas politik tidak hanya didasarkan kepada asumsi besarnya suatu peristiwa politik, namun juga nilai politik dari peristiwa itu. Nilai politik ini berkaitan dengan kepentingan media dan kepentingan masyarakat sebagai publik dari media tersebut. Aspek penting yang lain dari media massa selain faktor pesan adalah kemampuan media dalam membentuk/menggiring opini publik. Adanya opini publik dengan snowball effect sangat mungkin mendorong sikap dan perilaku atas suatu isu politik tertentu.

\section{Opini Publik}

Secara sosiologis, opini publik diartikan sebagai kekuatan yang ada pada masyarakat. Kekuatan itu tak berasal dari pendapat orang per orang, namun dari norma atau mitos yang tumbuh di dalam masyarakat. Persepsi negatif masyarakat kepada partai politik salah satunya ditimbulkan karena akses informasi yang mudah didapat, misal melalui internet. Publik selalu menyatakan bahwa partai politik hanya peduli pada kepentingan partainya, banyak berjanji tapi tidak menepati janji-janjinya dan lebih suka berbicara tentang diri (kepentingan) mereka sendiri. Dengan ingatan negatif seperti ini, tidak heran jika tingkat kepercayaan publik akan selalu rendah kepada partai politik.

Menurut Cutlip dan Center (dalam Sastropoetro, 1990) opini publik dapat terbentuk setelah melalui empat tahap berikut ini.

a. Ada masalah yang perlu dipecahkan sehingga orang mencari alternatif pemecahan.

b. Munculnya beberapa alternatif yang memungkinkan terjadinya diskusi untuk memilih alternatif.

c. Dalam diskusi diambil sebuah keputusan yang melahirkan kesadaran kelompok.

d. Untuk melaksanakan keputusan, disusunlah program yang memerlukan dukungan lebih luas.

Sementara itu, Erikson dan Tedin (2014) mengemukakan 4 tahap pembentukan opini publik sebagai berikut.

a. Muncul isu yang dirasakan amat relevan bagi kehidupan orang banyak.

b. Isu itu relatif baru sehingga memunculkan kekaburan standar penilaian (standar ganda).

c. Terdapat opinion leaders (tokoh pembentuk opini), yang juga tertarik dengan isu tersebut, misalnya politisi atau akademisi.

d. Mendapat perhatian dari pers hingga informasi dan reaksi terhadap isu tersebut diketahui khalayak.

Opini publik juga bisa muncul karena adanya isu-isu kontroversial. George Carslake Thompson (dalam Olii, 2007) menyatakan bahwa publik tertentu yang menghadapi isu kontroversial bisa mengeluarkan reaksi yang berbeda sehingga mengakibatkan kondisi yang juga berbeda. Perbedaan itu disebabkan tiga hal, yaitu perbedaan pandangan terhadap fakta, perbedaan perkiraan tentang cara mencapai tujuan serta perbedaan motif yang serupa untuk mencapai tujuan.

Ferdinand Tonnies (dalam Nurudin, 2001: 56-57), menyatakan tiga tahap pembentukan opini publik: (1) Luftartigen 
Position, posisi bak angin yang adalah tahap masukan yang masih semrawut; (2) Fleissigen Position, yaitu tahap pembicaraan yang mulai terarah membentuk pikiran yang jelas dan menyatu di mana dalam tahap ini isu dapat disetujui dan tidak; dan (3) Festigen Position atau tahap yang bisa menyatukan pendapat para anggota kelompok dari tahap-tahap sebelumnya.

\section{Kredibilitas Komunikator Politik}

Salah satu variabel terpenting yang memengaruhi perubahan sikap penerima pesan adalah kredibilitas komunikator. Jika seorang komunikator politik memiliki tingkat kredibilitas yang tinggi di mata khalayak maka hal itu akan memudahkan dalam proses transfer ide, gagasan, maupun pesan-pesan politik. Sebaliknya, Apabila di mata khalayak seorang komunikator politik punya kredibilitas rendah atau bahkan sulit dipertanggungjawabkan maka yang selanjutnya terjadi adalah kegagalan dalam proses komunikasi.

Kredibilitas adalah aspek pertama dan utama agar persuasi politik berjalan efektif. Aristoteles memakai istilah ethos untuk menggambarkan krebibilitas seorang komunikator politik. Dalam berbagai studi empiris yang dilakukan selama beberapa dekade ini, kredibilitas selalu terdiri dari berbagai aspek. Tiga aspek utama kredibilitas adalah keahlian (expertise), dapat dipercaya (trustworthiness) dan kepedulian (good will) (McCroskey \& Teven, 1999). Beberapa aspek yang tercakup dalam keahlian (expertise) adalah pengetahuan, pengalaman politik dan kemampuan yang seharusnya dimiliki seorang komunikator politik. Dapat dipercaya (trustworthiness) adalah integritas yang dimiliki oleh komunikator politik: jujur, berwatak baik dan selaras antara ucapan dan tindakan. Kepedulian (good will) terkait dengan empati dan kemampuan memahami penderitaan orang lain.

Menurut Rogers dan Shoemaker, kredibilitas adalah the degree to wich a communication source or channel is perceived as trustworthy and comptent by the receiver (dalam Siregar, 1990: 1). Trustworthy (kejujuran) berkaitan dengan kesan dari penerima atas sifat atau karakter dari sumber. Sedangkan competent atau sering disebut expertness terkaiat dengan kesan penerima atas keahlian yang dimiliki sumber.

Sementara itu, Aristoteles menyebut karakter komunikator sebagai ethos, yang terdiri dari itikad baik (good will), pikiran yang baik atau good sense dan karakter yang baik (good moral character) (Ardianto, 2007: 33). Ethos ditujukan untuk proses persuasi, yang mana efek dari komunikasi itu adalah untuk mengubah perilaku. Tapi komunikasi yang bersifat informatif pun mengharapkan adanya penambahan pengetahuan dan pengalaman dari komunikannya. Komunikator yang mempunyai ethos akan menghasilkan komunikasi yang efektif yaitu komunikasi yang dapat mencapai tujuannya. Sedangkan komunikator yang tidak memiliki good will, bisa diidentifikasi sebagai provokator.

Selain apa yang telah dijelaskan di atas masih ada hal yang kiranya perlu diperhatikan untuk menjadi seorang komunikator politik yang baik, yaitu keteladanan. Keteladanan juga berperan penting dalam membangun hubungan antara komunikator dan komunikan. Bagaimana mungkin orang akan mempercayai ucapan seorang politisi jika sang politisi tidak memberi teladan atau contoh yang baik/pantas/etis kepada segenap konstituennya.

Dalam penyampaian pesan politik, supaya praktik persuasi berjalan efektif, komunikator politik dapat menyampaikan pesan politiknya dalam bentuk cerita (narasi). Selain dapat mengetengahkan suatu persoalan dan menawarkan solusi pemecahannya, sebuah pesan yang disampaikan secara naratif dapat disampaikan secara dramatis (Hinyard dan Kreuter, 2007). Pesan naratif dianggap dapat menyihir para pendengarnya, ikut melibatkan mereka dalam sebuah cerita 
(persoalan kebangsaan) sekaligus menjanjikan pemecahan masalah.

Dalam keahlian (expertise), disebutkan bagaimana Richard Nixon mampu menyampaikan pesan yang menunjukkan dirinya sebagai pribadi yang cerdas, memahami berbagai persoalan internasional dan memahami dinamika dunia politik. Singkatnya, Nixon dapat memperlihatkan dirinya sebagai politisi ulung. Dalam hal dapat dipercaya (trustworthiness), contoh yang jelas adalah Jimmy Carter. Guna mengatasi ketidakpercayaan publik, akibat Skandal Watergate yang melibatkan Nixon, Carter berjanji bahwa ia tidak akan pernah berbohong pada rakyat Amerika. Dalam hal kepedulian (good will), contoh yang diperlihatkan adalah konstestasi di antara Obama dan Romney, di mana Obama dapat memperlihatkan empatinya terhadap rakyat Amerika yang sedang berjuang memperbaiki keadaan ekonomi dan pengangguran (Perloff, 2014).

\section{Keteladanan, Amanah (Dapat Dipercaya) dan Itikad Baik (Niat)}

Kredibilitas adalah aspek pertama dan utama agar persuasi politik berjalan efektif. Aristoteles memakai istilah ethos untuk menggambarkan kredibilitas seorang komunikator (politikus). Dalam berbagai studi empiris yang dilakukan selama beberapa dekade ini, kredibilitas selalu terdiri dari berbagai aspek. McCroskey dan Teven (1999) menyebutkan 3 unsur utama kredibilitas: trustworthiness (kejujuran), expertise (keahlian) dan good will (itikad baik). Rogers dan Shoemaker (dalm Siregar, 1990: 1) menyebutkan dua unsur dalam kredibilitas, yaitu trustworthy (kejujuran) dan competent atau keahlian. Sementara itu, Aristoteles menyebutkan 3 unsur kredibilitas seorang komunikator politik, terdiri dari pikiran baik (good sense), itikad baik (good will) dan karakter yang baik good moral character) (Ardianto, 2007: 33).

Selain apa yang telah dijelaskan di atas masih ada hal yang kiranya perlu diperhatikan untuk menjadi seorang komunikator politik yang baik, yaitu keteladanan. Keteladanan juga berperan penting dalam membangun hubungan antara komunikator dan komunikan. Bagaimana mungkin orang akan mempercayai ucapan seorang politisi jika sang politisi tidak memberi teladan atau contoh yang baik/pantas/etis kepada segenap konstituennya.

Dalam Kamus Besar Bahasa Indonesia (KBBI) keteladanan berasal dari kata teladan yang artinya hal yang bisa ditiru atau dicontoh. Menurut Hidayatullah (2010: 43), setidaknya terdapat 3 unsur agar seseorang dapat diteladani atau menjadi teladan.

a. Kesiapan untuk Dinilai dan Dievaluasi

Kesiapan menjadi cermin baik bagi dirinya sendiri maupun bagi orang lain. Kondisi ini akan berdampak pada kehidupan sosial di masyarakat, karena ucapan, sikap dan perilakunya menjadi sorotan dan teladan.

b. Memiliki Kompetensi Minimal

Seseorang dapat menjadi teladan apabila mempnyai ucapan, sikap dan perilaku untuk diteladani. Kompetensi yang dimaksud adalah kondisi minimal ucapan, sikap dan perilaku yang harus dimiliki sehingga dapat dijadikan cermin baik bagi dirinya sendiri maupun orang lain.

c. Memiliki Integritas Moral

Integritas merupakan adanya kesamaan antara apa yang diucapkan dan apa yang dilakukan. Inti integritas terletak pada kualitas ketetapannya, yaitu komitmen dan konsistensi terhadap profesi yang diembannya.

Aspek lainnya yang merupakan bagian dari kredibilitas komuikator politik adalah amanah. Definisi amanah sendiri sangatlah luas cakupannya, meliputi segala yang berkaitan hubungan interpersonal antarmanusia serta hubungan dengan sang pencipta. Menurut Ibnu Katsir (2013) amanah ialah semua tugas atau pembebanan agama yang meliputi perkara-perkara dunia dan 
akhirat yang ditujukan kepada manusia. Dari segi bahasa, kata amanah berasal dari bahasa arab, artinya aman, jujur dan bisa dipercaya. Sementara dalam Kamus Besar Bahasa Indonesia (KBBI) amanah merupakan sesuatu yang dititipkan kepada orang lain, setia, dan bisa dipercaya. Orang amanah adalah orang yang dapat menjalankan tugas yang diberikan.

Menurut Hamka (1990), amanah merupakan pondasi dasar dalam kehidupan bermasyarakat dan bernegara. Amanah menjadi perekat sosial dalam membangun solidaritas masyarakat yng bertujuan membentuk kerja sama antarsesama individu (Pulungan, 2006). Tanpa amanah, kehidupan masyarakat dan bernegara menjadi rusak. Banyak perilaku kriminal atau konflik karena tidak amanah dalam menjalankan tugas dan berperilaku.

Sebagai kualitas individu, amanah sebagai sifat baik harus dipunyai oleh setiap muslim, seperti bertanggung jawab, jujur dan menunaikan janji (dalam Agung dan Husni, 2016). Konsep amanah dan keterpercayaan pada individu terletk pada karakter dan perilaku positif dari individu itu sendiri, kejujuran, tanggung jawab, konsistensi dan lain-lain. Artinya individu bisa dikatakan amanah jika ia bisa meyelesaikan tugas yang diberikan padanya.

Di samping keteladanan dan amanah, kredibilitas komunikator bisa dilihat aspek lainnya, yaitu itikad baik atau niat baik. Menurut Theory of Planned Behavior, seseorang dapat bertindak berdasarkan intensi/niatnya hanya jika ia mempunyai kontrol terhadp perilakunya (Ajzen, 2002). Teori ini Teori ini tidak hanya menekankan kepada rasionalitas dari tingkah laku manusia, tetapi juga pada belief bahwa target tingkah laku berada di bawah kontrol kesadaran individu. Suatu tingkah laku tak hanya bergantung pada niat seseorang, melainkan juga faktor lain yang tidak ada di bawah kontrol individu, misal ketersediaan sumber dan kesempatan menampilkan tingkah laku tersebut.
Niat merupakan sebuah istilah yang berkaitan dengan tindakan dan merupakan unsur penting pada sejumlah tindakan, yang menunjukan pada keadaan pikiran seseorang yang diarahkan guna melakukan suatu tindakan, yang senyatanya bisa atau tidak bisa dilakukan dan diarahkan entah pada tindakan sekarang atau pada tindakan yang akan datang.

Niat (intention) merupakan pondasi atau dasar yang sangat penting bagi perilaku/tindakan, bahkan menjdi barometer setiap perilaku/tindakan. Nilai suatu perilaku sangat tergantung kepada niat. Jika niatnya baik maka perilaku menjadi baik. Sebaliknya, jika niat buruk, perilaku juga menjadi buruk (Nawawi dalam Murtadho \& Salafuddin, 2001). Ibnul Qayyim mengungkapkan jika niat berkaitan dengan pekerjaan yang memungkinkan dilaksanakan dan yang tak mungkin dilaksanakan, dan ini berbeda dengan tujuan dan harapan. Keduanya tidak berhubungan dengan suatu pekerjaan yang tidak mungkin untuk dilaksanakan baik oleh dirinya sendiri maupun orang lain. Karena itu, niat lebih umum daripada tujuan. Sedangkan Daraz mengatakan bahwa niat ialah gerakan, yang dengan gerakan itu seseorang dapat melakukan kehendaknya dengan benar-benar melakukan sesuatu hal yang dikehendaki (dalam Al-Asyqar, 2006).

\section{METODE PENELITIAN}

Penelitian ini memakai paradigma postpositivisme yang merupakan perbaikan atau koreksi atas positivisme yang dianggap memiliki kelemahan-kelemahan, dianggap hanya mengandalkan kemampuan pengamatan langsung pada objek yang diteliti. Menurut Muhadjir (2000) postpositivisme merupakan pencarian makna di balik data.

Menurut Guba dan Lincoln (dalam Denzin dan Lincoln [Eds.], 1994), paradigma membantu mengarahkan metode \& pola berpikir peneliti sehingga penelitian bisa tepat berada dalam pola dan metode berpikir tertentu. 
Penelitian ini menggunakan pendekatan kualitatif yang adalah tradisi tertentu dalam ilmu pengetahuan sosial yang secara mendasar (fundamental) bergantung pada pengamatan atas manusia dan kawasannya sendiri sekaligus berhubungan dengan orang-orang tersebut dalam bahasa dan peristilahannya. Tujuan dari penelitian kualitatif adalah memahami apa yang tersembunyi di balik fenomena yang terkadang merupakan sesuatu yang sulit diketahui atau dipahami (Moelong, 2007).

Penelitian kualitatif juga mampu memperhatikan pengalaman individu dalam menghadapi masyarakat pada kehidupan sehari-hari serta mempelajari mengenai kelompok dan berbagai pengamalan yang mungkin tidak diketahui sebelumnya (Bogdan \& Taylor, 1998: 4-5). Penelitian kualitatif bermaksud memahami fenomena mengenai apa yang dialami subjek penelitian, misalnya perilaku, persepsi, motivasi, tindakan dan lain-lain secara holistik, dan dengan suatu deskripsi dalam bentuk kata-kata dan bahasa, pada suatu konteks khusus yang alamiah dan dengan memanfaatkan berbagai metode alamiah (Moelong, 2007).

Hasil penelitian tidak berusaha digeneralisasi, namun tetap subjektif, karena pendekatan kualitatif percaya apabila semua fenomena sosial berbeda-beda, tergantung dari konteks, latar belakang dan kondisi pribadi individu. Pendekatan kualitatif bersifat fleksibel dan memungkinkan data beserta teori berinteraksi dengan sendirinya (Patton, 2002: 68-69).

Penggunaan pendekatan kualitatif dalam penelitian ini bertujuan untuk memperoleh gambaran tentang propaganda Hak Angket DPR terhadap KPK. Pendekatan kualitatif yang digunakan dalam penelitian ini diharapkan dapat memberi jawaban/informasi secara ringkas dan mendalam. Sementara desain penelitian yang digunakan adalah desain penelitian deskriptif dengan tujuan mendeskripsikan apa serta bagaimana propaganda Hak Angket DPR terhadap KPK.

\section{PEMBAHASAN}

Dewan Perwakilan Rakyat (DPR) mengesahkan pembentukan Pansus Hak Angket KPK tanggal 30 Mei 2017. Pansus Hak Angket KPK tetap dibentuk meskipun ada banyak penolakan baik itu dari masyarakat maupun dari beberapa fraksi di DPR itu sendiri. Salah satu bentuk penolakan yang berasal dari masyarakat antara lain oleh 357 profesor dari berbagai perguruan tinggi di Indonesia. Terlepas dari berbagai pro-kontra, Pansus tetap akan menjalani tugasnya menggali keterangan mengenai fungsi pemberantasan korupsi yang dilakukan KPK.

Usul penggunaan Hak Angket itu sendiri pertama kali muncul dalam rapat dengar pendapat (RDP) antara Komisi III bersama KPK. Pada pertemuan tersebut, Komisi III meminta (mendesak) KPK agar mau membuka rekaman pemeriksaan terhadap Miryam S Haryani, karena dalam rekaman tersebut ada pernyataan yang menyebutkan adanya tekanan dari anggota Komisi III DPR. Menurut penyidik KPK, Miryam mengaku ditekan anggota Komisi III, antara lain oleh Bambang Soesatyo, Aziz Syamsudin, Desmon J. Mahesa, Masinton Pasaribu dan Sarifuddin Sudding.

Hak Angket itu sendiri diatur dalam pasal 79 ayat (3) Undang-undang No.17 tahun 2014 yang menyebutkan bahwa Hak Angket merupakan hak DPR untuk melakukan penyelidikan terhadap pelaksanaan undangundang dan/atau kebijakan pemerintah yang terkait hal penting, strategis serta berdampak luas bagi kehidpan bermasyarakat, berbangsa, bernegara yang diduga bertentangan dengan peraturan perundang-undangan.

Persoalan Hak Angket DPR kepada KPK yang mengemuka cenderung banyak diwarnai propaganda politik ketimbang sebagai upaya yang dilakukan DPR memperkuat KPK. Berbagai isu yang dijadikan sebagai propaganda DPR terhadap KPK cenderung kontraproduktif di tengahtengah gencarnya gerakan KPK memberantas korupsi. Baik disadari maupun tidak, berbagai 
propaganda yang dilakukan DPR terhadap KPK merupakan bagian dari upaya membentuk opini publik tandingan, yang mana dalam hal ini kredibilitas KPK berada jauh di atas DPR di mata masyarakat.

Oleh sebab itu, permasalahan ini menarik untuk dikaji dari perspektif komunikasi politik. Alih-alih berupaya untuk membangun komunikasi politik yang persuasif (dialog), DPR malah melancarkan propaganda melalui berbagai saluran yang tersedia baik vertikal (media massa) maupun horizontal. Perilaku tersebut secara tidak langsung memperlihatkan ketidakmatangan para politisi di senayan dalam mengelola komunikasi politik. Akibatnya, ada banyak opini publik yang berkembang baik versi DPR maupun KPK.

\section{Isu-Isu di Balik Propaganda Hak Angket}

Dari isu-isu yang digulirkan Pansus Hak Angket, terlihat bagaimana Hak Angket yang diajukan DPR tak relevan, karena halhal yang dipersoalkan sebenarnya bisa diselesaikan lewat rapat kerja antara DPR dan KPK. Isu yang pertama adalah perlunya beberapa anggota DPR melakukan investigasi kepada nama-nama anggota DPR yang disebut oleh Miryam Haryani ketika ia sedang diperiksa oleh KPK dalam kasus korupsi EKTP. Selain itu, DPR juga minta agar KPK menyerahkan BAP dan membuka rekaman pemeriksaan terhadap Miryam untuk diinvestigasi.

Pelontaran dua isu tersebut pada awalawal pembentukan Pansus jelas-jelas tidak masuk akal karena tak sesuai dengan tugas dan fungsi DPR sebagai lembaga legislatif. Namun sebagai bagian dari propaganda menjaga citra baik DPR, kedua isu tersebut dapat menjadi semacam pembelaan terhadap publik bahwa apa yang disampaikan Miryam dalam kesaksiannya, bahwa ada banyak anggota DPR yang terlibat dalam korupsi EKTP, tidak benar.

Berdasarkan dua isu tersebut, Hak Angket yang digulirkan cenderung seperti bentuk perlawanan dari DPR kepada KPK yang tengah mengusut kasus E-KTP yang diduga melibatkan banyak anggota DPR. Oleh karena itu, upaya propaganda yang dilakukan secara vertikal, khususnya melalui pemberitaan-pemberitaan di media massa, dianggap dapat menjadi upaya tersendiri dalam menjaga citra DPR sebagai lembaga legislatif.

Isu berikutnya yang kemudian dijadikan propaganda adalah Laporan Hasil Pemeriksaan (LHP) kepatuhan KPK tahun 2015 menyangkut tata kelola anggaran. Dalam laporan tersebut, disebutkan 7 indikasi ketidakpatuhan KPK terhadap peraturan perundang-undangan.

Pertama adalah kelebihan pembayaran gaji pegawai KPK yang belum diselesaikan atas pelaksanaan tugas belajar. Kedua adalah belanja barang pada direktorat monitor kedeputian informasi dan data yang tak dilengkapi dengan pertanggungjawaban yang memadai dan tak sesuai mata anggarannya. Ketiga adalah pembayaran belanja perjalanan dinas, belanja sewa, belanja jasa profesi pada biro hukum. Keempat, kegiatan perjalanan dinas kedeputian penindakan yang tidak didukung surat perintah. Kelima adalah standar biaya pembayaran atas, honorarium kedeputian penindakan. Keenam, realisasi belanja perjalanan dinas biasa yang tak sesuai dengan ketentuan minimal. Ketujuh, perencanaan gedung KPK yang tak cermat sehingga mengakibatkan kelebihan pembayaran (https://news.detik.com/berita/d3486828/ini-sederet-alasan-dpr-gulirkan-hakangket-kpk).

Paralel dengan kedua isu yang pertama, lagi-lagi propaganda dengan menggunakan LHP tersebut cenderung tidak substansial dan baru mengemuka setelah sekian lama. Artinya ketujuh indikasi yang disebutkan sebenarnya bisa dibahas dan diselesaikan melalui saluran komunikasi horizontal, misal lewat rapat antara DPR dan KPK, tidak disalurkan melalui saluran vertikal sehingga menjadi upaya propaganda dalam membangun opini publik negatif terhadap KPK. 
Isu lainnya yang juga digunakan sebagai propaganda negatif adalah isu yang terkait dengan tata kelola dokumentasi dalam proses hukum penindakan dugaan korupsi, seperti terjadinya kebocoran BAP, sprindik dan surat cekal.

Dari isu-isu tersebut, apa yang kemudian dipropagandakan DPR terkait pengguliran Hak Angket adalah sebagai bagian dari kewajiban dalam menjaga keberadaan KPK agar tak hanya kuat dalam melaksanakan tupoksinya, namun juga KPK cermat dan memperhatikan seluruh ketentuan hukum maupun HAM serta menerapkan prinsip transparansi dan akuntabilitas yang benar dalam tata kelola, termasuk dalam hal penggunaan anggaran.

Namun demikian, pembentukan Pansus Hak Angket tidak bisa terlepas dari kasus E-KTP yang sedang ditangani KPK, hal yang membuat propaganda DPR terhadap KPK terlihat jelas. Alih-alih membangun komunikasi organisasi (komunikasi antarlembaga) DPR malah melakukan propaganda lewat berbagai media massa yang hasilnya semakin memperkeruh keadaan. Publik pun lebih menilai bahwa isu-isu yang dilontarkan DPR terkait KPK cenderung beraroma politik ketimbang upaya memperkuat kewenangan KPK dalam pemberantasan korupsi.

Hal ini senada dengan apa yang dikatakan oleh Lasswell yang melihat propaganda dapat membawa masyarakat ke dalam situasi bingung, ragu-ragu dan terpaku kepada sesuatu yang licik dan tampaknya menipu. Isu-isu tersebut pada kenyataannya tidak membawa kepada pemecahan masalah. Sebaliknya, isu-isu tersebut malah membuat publik semakin bingung menyikapi persoalan yang sedang terjadi antara DPR dan KPK, terutama dalam konteks pengusutan kasus EKTP yang diduga banyak melibatkan angota DPR. Berbagai isu yang dipropagandakan tersebut merupakan bagian dari proses diseminasi informasi untuk memengaruhi sikap dan tingkah laku masyarakat, yang pada konteks ini cenderung lebih mempercayai KPK ketimbang DPR.

\section{Saluran Propaganda Hak Angket KPK}

Dalam melakukan propaganda, ada dua saluran yang bisa dipakai oleh propagandis, yaitu vertikal dan horizontal. Lewat saluran vertikal, penyebaran informasi dilakukan melalui media massa dan media baru. Pada propaganda horizontal, yang bekerja pada arus yang sejajar di antara anggota kelompok, penyebaran informasi dilakukan lebih melalui komunikasi interpersonal dan komunikasi organisasi (dalam Shahreza dan El-Yana, 2016).

Dalam konteks propaganda Hak Angket yang dilakukan DPR terhadap KPK, saluran yang digunakan adalah vertikal dan horizontal. Melalui saluran vertikal, Pansus Hak Angket tentunya sudah sering mengeluarkan pernyataan melalui media massa baik cetak maupun online, baik itu menyangkut legalitas pembentukan Pansus maupun perkembangan yang sudah dicapai oleh Pansus selama bekerja.

Upaya ini pada satu sisi merupakan propaganda yang bertujuan untuk meraih simpati masyarakat terkait kerja-kerja yang dilakukan oleh Pansus Hak Angket. Namun pada sisi lain, upaya ini juga secara tidak langsung berusaha mendiskreditkan KPK sebagai lembaga yang sedang bermasalah dan memang perlu dibenahi secara serius. Padahal, publik sudah menganggap KPK sebagai lembaga independen yang berhasil menangani persoalan korupsi di Indonesia pada saat ini, dibandingkan dengan institusi penegak hukum lainnya.

Tidak hanya melalui saluran vertikal upaya-upaya propaganda tersebut dilakukan, namun juga lewat saluran horizontal. Misalnya mengunjungi BPK guna berkoordinasi menyangkut laporan keuangan KPK, menyambangi Lapas Sukamiskin guna mengorek keterangan dari narapidana korupsi, mengunjungi Mabes Polri agar Polri membantu investigasi mereka, mengunjungi Kejaksaan Agung untuk mendalami prosedur 
penuntutan di dalam tindak pidana korupsi. Upaya tersebut tentu dapat memberi citra positif bagi keberadaan Pansus Hak Angket sebab secara tidak langsung keberadaan Pansus Hak Angket mendapat dukungan dari institusi-institusi yang dikunjunginya.

Upaya yang dilakukan melalui saluran horizontal ini dirasakan sangat kontradiktif. Sebagai lembaga yang sedang berseteru dengan KPK, seharusnya DPR terlebih dulu membangun komunikasi politik dengan KPK sebagai upaya penyelesaian konflik, yang bersumber dari penolakan KPK membuka rekaman Miryam Haryani.

Dalam komunikasi politik, konflik dianggap sebagai suatu noise dalam proses penyampaian pesan. Menurut McNair (2011), semakin intens konflik terjadi pada sebuah organisasi maka fenomena noise juga menjadi sangat tidak kondusif. Metode yang tepat hanya mereduksi konflik sampai ke tingkat yang paling minimal atau melakukan tindakan pencegahan. Apabila dua hal itu sulit dilakukan, diperlukan langkah progesif untuk menemukan model pemecahan atau resolusi konflik yang tepat, relevan dan aplikatif. Upaya terakhir ini dapat menjadi solusi strategis agar organisasi terhindar dan selamat dari kehancuran.

Sebab itu, tidak berlebihan jika berbagai saluran komunikasi horizontal yang dimanfaatkan DPR lebih cenderung menjadi ajang propaganda daripada menjadi upaya penyelesaian masalah. Padahal, upaya dialog yang diupayakan DPR tidak mustahil mampu memperbaiki citra DPR yang terlanjur dipandang buruk oleh masyarakat. Melalui pengupayaan dialog, masyarakat akan menilai jika DPR memang serius mendukung KPK dalam hal pemberantasan korupsi.

Namun yang terjadi tidaklah demikian. DPR tetap bersikukuh dengan pendapatnya yang meyakini bahwa ada pelanggaran yang dilakukan oleh KPK dalam menjalani fungsi dan kewajibannya, sementara KPK bersikukuh bahwa apa yang dilakukannya (enggan menyerahkan rekaman pemeriksaan Miryam) sudah sesuai dengan undang-undang yang berlaku atau masih di dalam koridor hukum.

Penggunaan saluran propaganda secara vertikal dan horizontal dalam konteks ini pada akhirnya bertujuan untuk membentuk opini publik tandingan. Bagaimanapun juga, masyarakat terlihat lebih percaya kepada KPK dibanding DPR dalam hal menjalani fungsi dan tanggung jawabnya. Pembentukan opini publik tandingan ini antara lain bertujuan agar publik menaruh simpati kepada DPR sebagai pihak yang dizalimi KPK (karena KPK menolak untuk membuka rekaman pemeriksaan Miryam Haryani) dan adanya persoalan yang signifikan di dalam tubuh KPK sebagaimana tertuang dalam Laporan Hasil Pemeriksaan (LHP) kepatuhan KPK tahun 2015.

Pembentukan opini publik tandingan yang dilakukan oleh DPR itu juga sudah melalui 4 tahapan sebagaimana dikemukakan Cutlip dan Center (dalam Sastropoetro, 1990). Tahap yang pertama adalah terdapat masalah yang perlu dipecahkan sehingga orang mencari alternatif pemecahan. Tahap pertama ini dapat dilihat saat DPR mulai mewacanakan Hak Angket terhadap KPK ketika KPK menolak untuk membuka rekaman pemeriksaan Miryam Haryani. Jadi, Hak Angket dianggap sebagai alternatif pemecahan masalah dan solusi. Tahap yang kedua adalah munculnya beberapa alternatif memungkinkan terjadinya diskusi untuk memilih alternatif. Tahap ini berlangsung sepanjang berjalannya proses pembentukan Pansus Hak Angket. Tahap yang selanjutnya merupakan pengambilan keputusan yang melahirkan kesadaran kelompok. Tahap ini bisa terlihat sewaktu disahkannya pembentukan Pansus Hak Angket. Adapun tahap yang terakhir adalah pelaksanaan keputusan dengan menyusun program yang membutuhkan dukungan lebih luas. Tahapan ini dapat dilihat dari serangkaian program kerja yang dirumuskan Pansus Hak Angket terutama dalam menggali keterangan mengenai fungsi pemberantasan korupsi yang 
dilakukan oleh KPK sebagai lembaga penegak hukum.

\section{Kredibilitas DPR sebagai Komunikator Politik (Propagandis)}

Efektivitas komunikasi tidak saja ditentukan kemampuan komunikasi, tapi juga didukung oleh diri komunikator. Kegiatan komunikasi akan berjalan dengan baik apabila komunikatornya mempunyai kemampuan menyampaikan pesan dan informasi kepada komunikan (publik) sehingga komunikan menjadi tahu atau bahkan berubah sikap, pendapat dan perilakunya. Tanpa kredibilitas, proses penyampaian informasi/pesan politik kemungkinan tidak akan efektif.

Komunikator dalam sebuah forum haruslah menjadi contoh yang patut untuk diteladani oleh khalayak. Dia harus memiliki kemampuan dan keahlian sesuai dengan apa yang dia bicarakan. Terhadap sikap dan kejujurannya dalam membawakan pesan juga memberikan konstribusi besar untuk mendapatkan perhatian. Di samping itu, performance dan empati yang ditunjukkan selama proses komunikasi berlangsung termasuk setelah berlangsungnya komunikasi itu, dipercaya akan semakin menambah keyakinan audience terhadap apa yang disampaikannya.

Dari segi keteladanan, sampai saat ini para politisi yang duduk di DPR masih jauh dari citra/gambaran sebagai teladan yang baik di mata masyarakat. Menerima gaji puluhan juta rupiah setiap bulan yang berasal dari uang rakyat, DPR belum juga menorehkan prestasi yang menggembirakan. Bahkan, publik sudah tidak asing lagi jika mendengar berita buruk menyangkut sikap anggota DPR, mulai dari maen game saat rapat, tidur ketika sidang paripurna, absensi istimewa, merokok di ruang rapat, berkelahi antarsesama anggota DPR hingga nonton film porno.

Dengan citra yang sedemikian melekat, yang sudah menimbulkan rasa tidak percaya bagi publik, apakah publik tidak akan curiga dengan pengguliran Hak Angket. Apalagi pengajuan Hak Angket dilakukan di tengah-tengah kerja KPK membongkar kasus korupsi E-KTP. Lebih jauh lagi, publik akan menjadi semakin tidak percaya terhadap DPR karena dianggap membela koruptor yang terlibat kasus E-KTP.

Selain keteladanan, dimensi yang tak kalah pentingnya sebagai ukuran kredibilitas adalah kejujuran/dapat dipercaya. Sampai sejauh ini bisa dikatakan jika kepercayaan publik terhadap DPR sangatlah rendah, atau mungkin sudah apatis. Rendahnya tingkat kepercayaan masyarakat kepada DPR salah satunya dapat dilihat dari hasil survei yang dirilis pada bulan September 2017, di mana masyarakat beranggapan jika DPR tidak mendukung pemberantasan korupsi (Kompas, 12 September 2017).

Menurut hasil survei tersebut, pandangan publik yang menilai kinerja DPR terbilang sangat baik dalam pembuatan undang-undang hanyalah sebesar 4,6 persen. Mengenai pembahasan dan mengesahkan APBN hanya sebesar 2,9 persen. Sedangkan terkait pengawasan dan pelaksanaan undangundang hanya 4,1 persen. Menyangkut pengawasan dan pelaksanaan UU yang menilai cukup baik hanya 47,7 persen. Terkait pembahasan dan mengesahkan APBN sebesar 49,1 persen dan pembuatan undang-undang sebesar 50,7 persen.

Sementara itu, Global Corruption Barometer 2017 yang disusun oleh Transparency International menunjukkan, mayoritas responden di 31 propinsi di Indonesia menempatkan DPR sebagai lembaga paling korup (54 persen) diikuti birokrasi (50 persen) dan DPRD (47 persen) (Kompas, 26 April 2017). Sebagai pembanding, survei Litbang Kompas Februari 2016 menunjukkan 74,7 persen dari 510 responden di 12 kota besar menganggap KPK punya citra positif.

Selain minimnya segi keteladanan dan kejujuran/dapat dipercaya, segi lainnya yang juga tak kalah penting adalah ketiadaan itikad baik. Sebagaimana kita ketahui, inisiasi Hak Angket berasal dari DPR (Komisi III) dan karenanya inisiatif atau itikad baik untuk 
menyelesaikan persoalan atau perbedaan yang ada seharusnya juga berawal dari DPR.

Sebagaimana telah dijelaskan sebelumnya, khususnya mengenai aneka saluran propaganda yang digunakan Pansus Hak Angket terhadap KPK, hal ini memperlihatkan dengan jelas bagaimana tiadanya itikad baik (good will) dari DPR untuk menyelesaikan konflik yang ada. Ketika KPK menolak membuka rekaman pemeriksaan Miryam, DPR melalui Komisi III malah mewacanakan penggunaan Hak Angket alih-alih mengupayakan sebentuk komunikasi politik yang persuasif (dialog).

Penggunaan saluran propaganda yang dilakukan Pansus Hak Angket, baik saluran vertikal maupun horizontal, memperlihatkan sama sekali tak ada itikad baik untuk menyelesaikan persoalan yang ada. Alih-alih mengupayakan dialog sewaktu KPK menolak membuka rekaman pemeriksaan Miryam, DPR malah mengancam akan mengajukan Hak Angket dengan berbagai dalih yang terkesan dibuat-buat.

Tidak adanya keteladanan, bisa dipercaya dan itikad baik sebagaimana telah dijelaskan di atas, dapat menjadi tolak ukur jika propaganda Hak Angket DPR terhadap KPK tidak efektif. Artinya, DPR tidak mempunyai kredibilitas yang memadai dalam membangun opini negatif terhadap KPK lewat berbagai propagandanya. Terlebih, ada beberapa nama anggota DPR yang duduk dalam Pansus diduga terlibat kasus korupsi EKTP, seperti Agun Gunandjar Sudarsa yang menjadi saksi pada kasus dugaan korupsi EKTP yang sekaligus menjadi ketua Pansus Hak Angket.

Bagaimanapun juga, kredibilitas adalah aspek pertama dan utama agar persuasi politik berjalan efektif. Dalam konteks keteladanan, DPR berada jauh di bawah KPK dalam memberi keteladanan terhadap masyarakat. Hal ini dapat kita lihat dengan jelas dari banyaknya dukungan yang mengalir kepada KPK. Dalam hal kejujuran DPR tengah mendapat sorotan buruk di mata masyarakat, apalagi jika melihat berbagai hasil survei yang dilakukan tentang kepercayaan masyarakat terhadap DPR. Dalam hal itikad baik, DPR tak pernah melakukan upaya-upaya komunikasi antarlembaga atau dialog persuasif ketika usulannya ditolak KPK yang menginginkan agar rekaman pemeriksaan Miryam Haryani dibuka.

\section{KESIMPULAN}

Selama bergulirnya Hak Angket DPR kepada KPK, upaya dialog persuasif dari kedua belah pihak hampir tak ada. Alih-alih mengadakan dialog (komunikasi persuasif), DPR malah terus melakukan propaganda baik dilakukan lewat saluran vertikal maupun horizontal. Serangan demi serangan yang dilakukan oleh Pansus, baik disadari maupun tidak, telah membawa masyarakat ke dalam situasi bingung, karena kedua pihak yang berseteru merasa benar dan bersikeras dengan posisinya masing-masing. Upaya-upaya propaganda yang dilakukan kemudian akan bermuara pada opini publik: bahwa KPK telah melakukan suatu "kesalahan" dan diperlukan upaya perbaikan yang salah satunya dilakukan lewat pembentukan Pansus Hak Angket.

Tidak adanya keteladanan, bisa dipercaya dan itikad baik tentunya menjadi tolak ukur jika propaganda Hak Angket DPR terhadap KPK tidak efektif. Artinya, DPR tidak mempunyai kredibilitas yang memadai untuk membangun opini negatif kepada KPK lewat berbagai propagandanya. Terlebih, ada beberapa nama anggota DPR dalam Pansus diduga terlibat kasus korupsi E-KTP, seperti Agun Gunandjar Sudarsa yang merupakan ketua Pansus Hak Angket sekaligus menjadi saksi dalam kasus E-KTP.

Belajar dari kasus-kasus sebelumnya, Hak Angket tampaknya hanya akan menjadi sebuah keputusan normatif tanpa ada solusinya. Padahal Tata Tertib DPR menegaskan jika Hak Angket digunakan untuk menyelidiki kebijakan pemerintah yang penting dan strategis serta berdampak luas dalam kehidupan bermasyarakat dan 
bernegara yang diduga bertentangan dengan peraturan perundang-undangan.

\section{DAFTAR PUSTAKA}

Al-Asyqar, Umar Sulaiman. 2006. Fiqih Niat. Jakarta: Gema Insani Press.

Ardianto, Elvinaro, dkk. 2007. Komunikasi: Suatu Pengantar. Bandung: Simbiosa Rekatama Media.

Cangara, Hafied. 2011. Komunikasi Politik: Konsep, Teori dan Strategi. Jakarta: RajaGrafindo Persada.

Denzin, Norman K. and Yvonna S. Lincoln (Eds.). 1994. Handbook of Qualitative Research. Sage Publications.

Erikson, Robert dan Kent L. Tedin. 2014. American Public Opinion: Its Origins, Content and Impact. Routledge.

Hamka. 1990. Tasauf modern. Jakarta: Pustaka Panji Mas.

Hidayatullah, M. Furqon. 2010. Pendidikan Karakter: Membangun Peradaban Bangsa. Surakarta: Yuma Pustaka.

Ibnu Katsir. 2013. Tafsir Ibnu Katsir. Jakarta: Pustaka Imam Syafii.

Keane, John. 1991. The Media and Democracy. Polity.

McNair, Brian. 2011. An Introduction to Political Communication. Routledge.

Moleong, Lexy J. 2007. Metodologi Penelitian Kualitatif. Bandung: PT. Remaja Rosdakarya.

Muhadjir, Noeng. 2000. Metode Penelitian Kualitatif. Yogyakarta: Rake Sarasin.

Murtadho dan Salafuddin, 2001. Syarah Hadits Arba'in. Solo: Penerbit AlQowam.

Nimmo, Dan. 2006. Komunikasi Politik: Komunikator, Pesan dan Media. Bandung: PT. Remaja Rosdakarya.

Nurudin. 2001. Komunikasi Propaganda. Bandung: PT. Remaja Rosdakarya.

Olii, Helena. 2007. Opini Publik. Jakarta: PT. Indeks.

Patton, Michael Quinn. 2002. Qualitative Research \& Evaluation Methods. Sage Publications.
Perloff, Richard M. 2014. The Dynamics of Political Communication: Media and Politics in a Digital Age. Routledge.

Sastropoetro, Santoso. 1990. Komunikasi Sosial. Bandung: PT. Remaja Rosdakarya.

Shahreza, Mirza dan Korry El-Yana. 2016. Etika Komunikasi Politik. Tangerang: Indigo Media.

Siregar, Ashadi. 1990. Komunikasi Sosial. Yogyakarta: Badan Penelitian dan Pengembangan Fisipol.

Taylor, Steven J. and Robert Bogdan. 1998. Introduction to Qualitative Research Methods. Wiley.

\section{Jurnal dan Penelitian}

Ajzen, Icek. 2006. "Perceived Behavioral Control, Self-Efficacy, Locus of Control, and the Theory of Planned Behavior". Journal of Applied Social Psychology, 32, 665-683.

Hinyard, L.J., \& Kreuter, M.W. 2007. 'Using narrative communication as a tool for health behavior change: A conceptual, theoretical, and empirical overview". Health Education \& Behavior, 34, 777-792.

McCombs, Maxwell E. and Donald L. Shaw. 1972. "The Agenda-Setting Function of Mass Media". The Public Opinion Quarterly, Volume 36 Issue 2.

McCroskey, J.C., \& Teven, J.J. 1999. "Goodwill: A reexamination of the construct and its measurement. Communication Monographs, 66, 90103.

Pulungan, S. 2006. Wawasan Tentang Amanah dalam Al-Quran. Disertasi: UIN Syarif Hidayatullah.

\section{Peraturan Perundang-Undangan}

Undang-Undang No.17 Tahun 2014 tentang Majelis Permusyawaratan Rakyat, Dewan Perwakian Rakyat, Dewan Perwakilan Daerah, dan Dewan Perwakian Rakyat Daerah. 
Undang-Undang No.30 Tahun 2002 tentang KPK.

\section{Sumber Internet}

7 Perilaku Buruk Anggota DPR yang Tak Patut Dicontoh. (17 Meis 2017). Diakses dari: https://www.merdeka.com/peristiwa/7 -perilaku-buruk-anggota-dpr-yangtak-patut-dicontoh.html

Analisa Kritis Hak Angket DPR Terhadap KPK (Kasus Rekaman Miryam). (15 Juni 2017). Diakses dari: http://www.hukumpedia.com/ollenk98 /analisa-kritis-hak-angket-dprterhadap-kpk-kasus-rekaman-miryam

Hak Angket DPR terhadap KPK, Tidak Salah dan Tidak Benar. (09 Juli 2017). Diakses dari: http://www.hukumpedia.com/thegreatf ebry/hak-angket-dpr-terhadap-kpktidak-salah-dan-tidak-benar

Hak Angket terhadap KPK dan Kepanikan Senayan. (04 Mei 2017). Diakses dari: https://news.detik.com/kolom/d3491384/hak-angket-terhadap-kpkdan-kepanikan-senayan

Hak Angket, Mengawasi atau Mengancam KPK? (26 April 2017). Diakses dari: http://nasional.kompas.com/read/2017 /04/26/16023831/hak.angket.mengawa si.atau.mengancam.kpk.

ICW: 78 Persen Anggota Pansus Angket Memiliki Konflik Kepentingan dengan KPK. (11 Juni 2017). Diakses dari: https://babe.news/read/12885641/icw78-persen-anggota-pansus-angketmemiliki-konflik-kepentingandengan-kpk/

Ini Sederet Alasan DPR Gulirkan Hak Angket KPK. (28 April 2017). Diakses dari: https://news.detik.com/berita/d3486828/ini-sederet-alasan-dprgulirkan-hak-angket-kpk

Kepercayaan terhadap DPR Rendah, Para Wakil Rakyat Diminta Berkaca. (12 September 2017). Diakses dari: http://nasional.kompas.com/read/2017 /09/12/22453771/kepercayaanterhadap-dpr-rendah-para-wakilrakyat-diminta-berkaca

Konflik Kepentingan di Pansus Hak Angket KPK. (08 Juni 2017). Diakses dari: http://nasional.kompas.com/read/2017 /06/08/09332171/konflik.kepentingan. di.pansus.hak.angket.kpk 